\title{
A CONTROLLED SERIES OF COOKE-ARNETH POLYNUCLEAR COUNTS IN RHEUMATOID ARTHRITIS
}

\author{
BY \\ H. J. GIBSON and D. SHIERS \\ From the Royal National Hospital for Rheumatic Diseases, Bath
}

\begin{abstract}
Introduction
The Cooke-Arneth count, as a measure of the age of circulating neutrophils, is considered to be an indication of the presence or absence of active infection. For this reason, numerous studies have been made of the count in rheumatoid arthritis in order to estimate what part infection plays in this disease. Other modifications of the polynuclear count, such as the Schilling and filament-non-filament counts, which give substantially the same information, have also been employed. The results have not been entirely in agreement. Thus Hill (1931), Eaton (1932), Collins (1936), and Hartung and others (1936) have reported left shifts in a very high proportion of cases, approaching 100 per cent. Steinberg (1935) reported a left shift of the Schilling count in 78 per cent. of cases. Cecil (1933), who regarded the polynuclear count (Schilling) as " perhaps the most definite of all gauges of an infectious process ", found a left shift in 52 per cent. of cases of rheumatoid arthritis. He quoted unpublished data of Rezinoff, who found a shift to the left in 68 per cent. Kahlmeter (1938) on the other hand concluded from a study of 284 cases of rheumatoid arthritis that the infective hypothesis of its origin was unproved. This he stated as follows: "The fact that there is no increase in the total number of leucocytes nor any modification of the ArnethSchilling blood picture is fairly strong evidence against such an (infective) hypothesis." Gray and others (1935) recorded a shift to the left in only 28 per cent. of early cases, 17 per cent. of established cases, and 15 per cent. of advanced cases.

One of the present authors (Gibson, 1938) reported the average weighted mean in rheumatoid arthritis to be significantly to the left of that of osteo-arthritis, ankylosing spondylitis, and normal persons, but in many severe and active cases normal Cooke-Arneth counts were found. The most striking finding was the wide "scatter" of the results. Cases which

were clinically similar gave widely different counts. No significant correlation was seen between polynuclear count and erythrocyte sedimentation rate or haematocrit, but the unexpected result was obtained that the weighted mean was positively correlated with the neutrophil count. As the neutrophil count decreased, the Cooke-Arneth count showed an increasing left shift, and as the leucocyte count increased the shift was towards the normal. This is of interest in view of the fact that Collins (1937) reported the most marked shifts to the left to occur in cases of Felty's syndrome, in which neutropenia was a feature.

In a later study of the polynuclear count in all clinical types of rheumatism, Gibson and Kersley (1938) noted that the left shift in gout was more marked, on the average, than that in rheumatoid arthritis or in any other form of chronic rheumatism and that the difference between gout and rheumatoid arthritis was statistically significant. No one has proposed that gout is an infective disease, but these results suggested that a metabolic toxaemia, or tissue reaction to toxic trauma, as found in gout, can produce a left shift of the polynuclear count.

In view of these discrepancies and apparent anomalies it was thought that further information of value might be derived from series of counts made in cases of rheumatoid arthritis which were (a) clinically typical (b) of duration under five years, the series being controlled by counts made in the same town on non-rheumatic persons of the same age, sex, and social status suffering from non-infective lesions of the locomotor system. These were for the most part convalescent orthopaedic cases in a general hospital. The aim was to assess whether a left shift of the Arneth count occurred in cases of rheumatoid arthritis, and, if so, whether it could be taken as evidence that this disease was the result of an infective process.
\end{abstract}




\section{Methods}

Films were made from venous blood and slides were stained by Loishman's method. All counts were made by the same person (H. J. G.) and the criteria for classification proposed by Cooke and Ponder (1927) were rigidly followed. The " weighted mean " which expresses the result of each count is the mean number of lobes per nucleus in the neutrophil polymorphonuclear leucocytes. The question of what constitutes a normal polynuclear count is a complex one. Evidence has been quoted previously (Gibson, 1938) which indicates that the normal varies considerably in different parts of the world, possibly as a result of climatic conditions. In Bath the average weighted mean in fifty-five healthy persons was 2.43. Subsequent experience over nine years has shown that this is a serviceable standard for routine use in general work. It must be emphasized that the controls in this study were not normal healthy persons at work, but that they were, as far as clinical examination showed, free from any infective disease.

The blood sedimentation rate in both series was estimated by the Westergren method, the figure quoted being the millimetres fall in one hour.

\section{Results}

General Comparison of Case and Control Series.In Table 1 the results are classified in five groups. Five rheumatoid cases showed very marked shifts to the left with weighted mean under 1-60. No controls were found in this group. At the other end of the scale cases were more numerous than controls in the strictly normal group with weighted means of 2.50 to 2.79 and in the intermediate group 2.20 to 2.49 which may be regarded as a mild left shift merging into the normal. Finally in the group of weighted mean $1 \cdot 60$ to $2 \cdot 19$, showing a definite

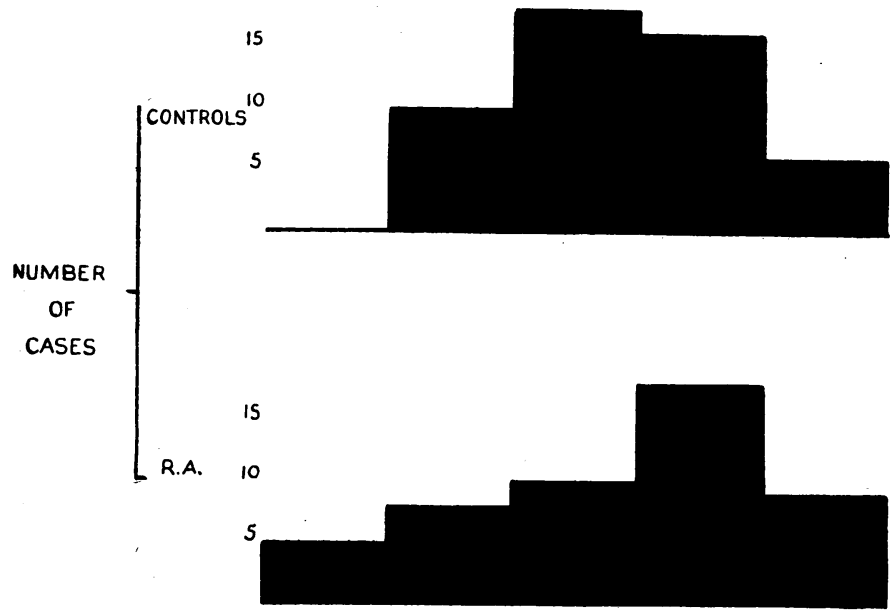

WEIGHTED MEANS, $1.3-1.59 \quad 1.60-1.89 \quad 1.90-2 \quad 19 \quad 2.20-2.49 \quad 2.50-2.79$

FIGURE.-Frequency distribution of weighted means of Cooke-Arneth counts in cases of rheumatoid arthritis and in controls.
TABLE 1

FREQUENCY DISTRIBUTION OF WEIGHTED MEANS IN RHEUMATOID ARTHRITIS CASES AND IN CONTROLS

\begin{tabular}{c|c|c}
\hline \multirow{2}{*}{$\begin{array}{c}\text { Weighted mean } \\
\text { range }\end{array}$} & \multicolumn{2}{|c}{ Number of cases } \\
\cline { 2 - 3 } & $\begin{array}{c}\text { Rheumatoid } \\
\text { arthritis }\end{array}$ & Controls \\
\hline $1 \cdot 30-1.59$ & 5 & 0 \\
$1 \cdot 60-1.89$ & 8 & 10 \\
$1.90-2.19$ & 10 & 18 \\
$2 \cdot 20-2.49$ & 18 & 16 \\
$2 \cdot 50-2.79$ & 9 & 6 \\
\hline
\end{tabular}

left shift, controls were much more numerous than cases, the figures being 28 and 18 respectively. The averages of the weighted means was 2.14 for cases and $2 \cdot 16$ for controls, a negligible discrepancy. Thus, the only difference between the groups was one of distribution, the rheumatoid series showing a wider scatter than the controls, which were more closely grouped about the mean (see Figure).

It may be noted that the previous series reported by Gibson (1938) gave the average number of lobes per neutropnil in 345 cases of rheumatoid arthritis as 2.245 . In that series there was a predominance of very old-standing cases, the normal population of a rheumatic diseases hospital. The present series included only relatively early cases.

Further Analysis of Rheumatoid Arthritis Group.It was desired to find whether the widely varying counts in the rheumatoid group could be correlated with any other feature of the case. Thus, if a left shift were directly related to aetiology it might be expected to vary with activity as shown by the erythrocyte sedimentation rate.

The relevant figures are given in Table 2. It will be seen that in each blood sedimentation rate group a wide range of weighted means is represented and, in view of the small . numbers in some of the groups and the wide scatter of the figures, the average weighted mean is relatively constant. It shows no tendency to rise or fall in a regular way with increasing sedimentation rate. The results confirm the absence of correlation in the large series reported by Gibson (1938).

Duration of the Disease.-The duration of the disease and its 
TABLE 2

ARNETH COUNT AND ERYTHROCYTE SEDIMENTATION RATE (WESTERGREN METHOD) IN RHEUMATOID ARTHRITIS CASES

\begin{tabular}{c|c|c|c}
\hline $\begin{array}{c}\text { E.S.R. mm. } \\
\text { fall in 1 hr. }\end{array}$ & No. of cases & $\begin{array}{c}\text { Range of } \\
\text { weighted } \\
\text { mean }\end{array}$ & $\begin{array}{c}\text { Average } \\
\text { weighted } \\
\text { mean }\end{array}$ \\
\hline 9 & 4 & $1 \cdot 52-2 \cdot 41$ & $2 \cdot 178$ \\
$10-19$ & 15 & $1 \cdot 82-2 \cdot 64$ & $2 \cdot 216$ \\
$20-29$ & 9 & $1 \cdot 59-2 \cdot 55$ & $2 \cdot 316$ \\
$30-39$ & 8 & $1 \cdot 36-2 \cdot 62$ & 1.940 \\
$40-49$ & 6 & $1 \cdot 61-2 \cdot 54$ & $2 \cdot 240$ \\
$50-59$ & 1 & -1.910 \\
$60-69$ & 4 & $1 \cdot 41-2 \cdot 15$ & $1 \cdot 745$ \\
$70-79$ & 1 & $1 \cdot 81-2 \cdot 32$ & $2 \cdot 170$ \\
$80-89$ & 2 & 2.065 \\
\hline- & 50 & $1 \cdot 36-2 \cdot 64$ & $2 \cdot 140$ \\
\hline
\end{tabular}

TABLE 3

ARNETH COUNT AND DURATION OF RHEUMATOID ARTHRITIS

\begin{tabular}{c|c|c|c}
\hline $\begin{array}{c}\text { Duration of } \\
\text { disease } \\
\text { (years) }\end{array}$ & No. of cases & $\begin{array}{c}\text { Range of } \\
\text { weighted } \\
\text { means }\end{array}$ & $\begin{array}{c}\text { Mean } \\
\text { weighted } \\
\text { means }\end{array}$ \\
\hline $\begin{array}{c}\text { Under } 1 \\
1-2\end{array}$ & 12 & $1 \cdot 55-2 \cdot 55$ & $2 \cdot 16$ \\
$2-3$ & 13 & $1 \cdot 36-2.64$ & $2 \cdot 07$ \\
$3-4$ & 3 & $1 \cdot 41-2.54$ & $2 \cdot 17$ \\
$4-5$ & $7.83-2 \cdot 41$ & $2 \cdot 13$ \\
\hline Up to 5 & 50 & $1 \cdot 66-2 \cdot 62$ & $2 \cdot 18$ \\
\hline
\end{tabular}

relation to polynuclear count is shown in Table 3 . The average weighted mean remains practically constant, with no tendency to increase or diminish within the five-year period. In each group high and low weighted means are represented.

Age of Patient.-Table 4 shows that a similar wide range of values is included under each age period and that the average weighted mean is remarkably constant except when the number of cases is very low, as in the 60 to 69 age group.

Sex of Patient.-This is shown in Table 5. Although females show a more marked shift on the average than males, the range in each group is very wide and chance would account for the observed differences.

Results Expressed in Terms of the Non-filament Count.-In view of the fact that the non-filamentfilament count of Farley and others (1930) has been used by a number of workers in the United States, our figures have been calculated to express the results in that form, class one of the Cooke-Arneth count
TABLE 4

AGE OF PATIENT AND ARNETH COUNT IN RHEUMATOID ARTHRITIS

\begin{tabular}{|c|c|c|c|}
\hline Age & No. of cases & $\begin{array}{c}\text { Range of } \\
\text { weighted } \\
\text { mean }\end{array}$ & $\begin{array}{c}\text { Average } \\
\text { weighted } \\
\text { mean }\end{array}$ \\
\hline $\begin{array}{l}<19 \\
20-29 \\
30-39 \\
40-49 \\
50-59 \\
60-69\end{array}$ & $\begin{array}{r}5 \\
7 \\
8 \\
16 \\
12 \\
2\end{array}$ & $\begin{array}{l}1 \cdot 55-2 \cdot 55 \\
1 \cdot 41-2 \cdot 62 \\
1 \cdot 36-2 \cdot 55 \\
1 \cdot 52-2 \cdot 64 \\
1 \cdot 59-2 \cdot 55 \\
2 \cdot 17-2 \cdot 54\end{array}$ & $\begin{array}{l}2 \cdot 060 \\
2 \cdot 160 \\
2 \cdot 083 \\
2 \cdot 210 \\
2 \cdot 063 \\
2 \cdot 355\end{array}$ \\
\hline- & 50 & $1 \cdot 36-2 \cdot 64$ & $2 \cdot 149$ \\
\hline
\end{tabular}

TABLE 5

\section{SEX OF PATIENTS AND ARNETH COUNT} IN RHEUMATOID ARTHRITIS

\begin{tabular}{ll|c|c|c}
\hline \multicolumn{2}{c|}{ Sex } & No. of cases & $\begin{array}{c}\text { Range of } \\
\text { weighted } \\
\text { mean }\end{array}$ & $\begin{array}{c}\text { Average } \\
\text { weighted } \\
\text { mean }\end{array}$ \\
\hline Male &. & 20 & $\begin{array}{c}1.36-2.62 \\
1.41-2.64\end{array}$ & $\begin{array}{c}2.223 \\
2.093\end{array}$ \\
\hline
\end{tabular}

being the non-filament percentage. The average non-filament count was 26.5 per cent. in the rheumatoid group and 24.2 per cent. in controls. The normal non-filament percentage is 16 or less. Applying this standard we find that 32 of the case series had a left shift as compared with 33 controls. The difference is insignificant. This form of the polynuclear count did not, therefore, give a result materially different from the more inclusive CookeArneth count. Haden (1935) has pointed out that the Schilling and non-filament counts emphasize the immature forms while the Cooke-Arneth, which takes into account neutrophils of all ages, places emphasis on the more mature cells. In the present series the results are the same by both methods.

\section{Summary of Results}

Arneth Count.-Adopting the standard used by Collins (1936), if all counts with weighted mean of less than 2.40 are regarded as showing a left shift our results show such a shift in 72 per cent. of rheumatoid cases and 76 per cent. of controls. Our own standard in routine blood counting is less stringent. From an experience of many thousands of counts made in general medical and surgical cases at Bath, we are inclined to regard any weighted mean of 2.30 or more as normal. On this standard 
58 per cent. of rheumatoid cases and 64 per cent. of controls show a left shift.

Non-filament Count.-This method indicated that 64 per cent. of rheumatoid cases and 66 per cent. of controls showed a left shift.

By all methods the proportion of left shifts is greater in controls but the difference is not significant. The proportion of abnormal counts in rheumatoid cases is in general agreement with that found by a number of previous workers, but its significance is completely modified by the finding of an equal number of abnormal counts in controls.

\section{Discussion}

The most striking feature of the results is the high incidence of left shift in the control series and the close agreement between the results in cases and controls. All counts were made by one of us (H. J. G.), and so no error due to change of standards is involved. Throughout the whole duration of this study polynuclear counts have been made as a routine on general and rheumatic cases and the general run of results of these counts has been the same as during the past twelve years. The seasons involved were from November, 1946, till September, 1947, and included the severe weather early in 1947. The only notable epidemic was that of poliomyelitis, but no cases of this were found in the rheumatic hospital nor were any encountered in the general hospital where the controls were situated. The incidence of subclinical infection is an unknown factor. It may have influenced the figures in both groups.

In comparison with previous work the incidence of left shifts in our series occupies an intermediate position. It is higher than that reported by Gray and others (1935) and Kahlmeter (1938), and is of a similar order to the findings of Steinberg (1935), Cecil (1933), Rezinoff (1933) and of Short and others (1937) for cases of under one year's duration, but lower than the 93 per cent. noted by these workers for cases of more than one year's duration. The standard used by the last-named was very rigid. Combining myelocytes, juveniles, and band forms, they calculated these young cells as a percentage of total polymorphs and regarded more than 8 per cent. as indicative of a left shift. If we apply this standard to the present series all the rheumatoid cases would show a left shift as compared with 92 per cent. of controls.

Our case incidence of left shifts is very much below those reported by Hill (1931), Collins (1936), Steinbrocker and Hartung (1933), and Hartung and others (1936). When these discrepancies are scrutinized it is seen that the apparently great difference may be due partly to differences in interpretation and partly to sampling errors where results show such marked variation as they do in rheumatoid arthritis. Thus Collins found the average weighted mean in 39 female patients to be $2 \cdot 14$ and in 10 males to be $2 \cdot 11$, or $2 \cdot 13$ overall. This is practically the same as our average for the case series of $2 \cdot 14$. He regarded a weighted mean of 1.95 to 2.09 as a " marked left shift" and less than 1.95 as a " severe left shift". It may be noted that in enteric and abortus fevers, acute virus infections, and active tuberculosis, figures of the order of 1.05 to 1.4 are not uncommon. Thus our impression of a severe shift to left is a much more marked deviation than Collins describes.

Left shift of the polynuclear count is not necessarily indicative of infection. It is physiological in pregnancy and may be found following surgical operations and fractures where infection may be excluded. Tissue reaction of this kind may well account for the left shift in our control series. It is also the rule in many blood diseases and a familial form has been described by Peterson (1935). Again chemical toxaemia may also give rise to a left shift, either by destruction of more mature cells or by inhibition of maturation. Gout has already been mentioned. A recent case of sulphonamide intolerance with fever and skin rash yielded an Arneth count of $1 \cdot 16$. Three cases of thiouracil intolerance seen by one of us (H. J. G.) showed weighted means of $1.73,1.12$, and 1.09 when the neutrophil counts were $1420,396,22$ per c.mm. respectively. The similarity between these cases and the Felty group of rheumatoid arthritis in which Arneth left shift accompanies neutropenia is interesting.

The results of the present series show that there is no significant difference between the results of polynuclear counts in cases of rheumatoid arthritis and in controls in whom non-infective lesions of the locomotor system (old fractures) were present. Whether shifts are due to unrecognized septic foci, intercurrent infections, tissue reaction to aseptic inflammation, trauma, or chemical toxaemia, the rheumatoid arthritic cases showed no greater evidence of neutrophil reaction than did the non-rheumatic controls. The results argue against a direct infective aetiology of rheumatoid arthritis. The fact that the counts in this series showed no constant relation to activity or to duration is further evidence in the same direction. From the clinical point of view scrutiny of the case records repeatedly showed that an active case with widespread and severe rheumatoid involvement presented a normal count. This finding is quite unlike the results of similar counts in tuberculosis, syphilis, endocarditis lenta, or other true infections. 


\section{Summary and Conclusions}

Cooke-Arneth polynuclear counts have been made on fifty cases of rheumatoid arthritis, all typical in their clinical manifestations and of under five years' duration. They are compared with counts made by the same person on fifty controls of the same age and sex who were for the most part convalescent orthopaedic (fracture) cases.

No significant difference was noted between the results in cases and controls.

In the rheumatoid arthritis group no correlation was present between the polynuclear count and age, sex, erythrocyte sedimentation rate, clinical severity, or duration of the disease.

The results afford no support to the view that rheumatoid arthritis is the direct result of microorganismal infection.

Acknowledgement is made to the Physicians and Surgeons of the Royal National Hospital for Rheumatic Diseases and the Royal United Hospital, Bath, who have allowed us access to cases.

\section{REFERENCES}

Cecil, R. L. (1933). J. Amer. med. Ass., 100, 1220.

Collins, D. H. (1936). Acta Rheum. Amst., 8, 3. (1937). Third Ann. Rept. Brit. Committee on Chronic Rheum. Dis. London, p. 49.

Cooke, W. E., and Ponder, E. (1927). "The Polynuclear Count." London.

Eaton, E. R. (1932). Amer. J. Homoepath, 25, 125.

Farley, D. L., St. Clair, H., and Reisinger, J. A. (1930). Amer. J. med. Sci., 180, 336.

Gibson, H. J. (1938). Proc. roy. Soc. Med., 31, 309.

and Kersley, G. D. (1938). Med. Pr., 196, 353.
Gray, J. W., Bernhard, W. G., and Gowen, C. H. (1935). Amer. J. clin. Path., 5, 489.

Haden, R. L. (1935). Ibid., $5,354$.

Hartung, E. F., Davis, J. S., Steinbrocker, O., and Straub, M. E. (1936). J. Amer. med. Ass., 106, 1448.

Hill, L. C. (1931). Acta Rheum. Amst., 3, 6.

Kahlmeter, G. (1938). "A Survey of Chronic Rheumatic Diseases." Oxford University Press, London, p. 103.

Peterson, R. F. (1935). Amer. J. clin. Path., 5, 249.

Rezinoff, P. (1933). Quoted by Cecil (1933). Ibid., $100,1220$.

Short, C. L., Dienes, L., and Bauer, W. (1937). J. Amer. med. Ass., 108, 2087.

Steinberg, C. L. (1935). Amer. J. med. Sci., 190, 98.

Steinbrocker, O., and Hartung, E. F. (1933). J. Amer. med. Ass., 100, 654.

\section{Série Comparée de Numérations de Polynucléaires de Cooke-Arneth dans l'Arthrite Rhumatismale \\ RÉSUMÉ}

On a fait des numérations de polynucléaires de CookeArneth dans cinquante cas d'arthrite rhumatismale présentants tous des manifestations cliniques typiques et présentes depuis moins de cinq ans. Elles sont comparées avec des numérations faites pat la même personne sur cinquante témoins du même âge et du même sexe qui sont pour la plupart des convalescents de fractures.

On n'a constaté aucune différence significative entre les résultats obtenus pour les malades et pour les témoins.

Dans le groupe d'arthrite rhumatismale il n'existait aucune corrélation entre la numération des polynucléaires et l'âge, le sexe, le taux de sédimentation érythrocytaire, la gravité clinique ou la durée de la maladie.

Ces résultats n'apportent aucune confirmation à la théorie selon laquelle l'arthrite rhumatismale est le résultat direct d'une infection microbienne. 